\title{
Australia's Muslims strongly reject an association between Islam and violent extremism
}

Edition 4, 2020

Associate Professor Halim Rane

DOI: 10.37839/MAR2652-550X4.20

The association of Islam with violent extremism ranks highly among the defining issues and events of the 21st century so far. A 2019 study by the Pew Research Center found the threat of Islamist extremism topped the list of global concerns in a number of countries and ranked second in Australia after climate change.

Thinking about Islam in this way has been a major factor in perpetuating feelings of insecurity and the securitisation of society. However, Muslim Australians strongly reject an association between Islam and violent extremism, according to the findings of a recent national survey.

\section{About the survey}

The Islam in Australia survey was conducted by my team of researchers at Griffith University's Centre for Social and Cultural Research. It was fielded online in September and October 2019 with a focus on how Muslim Australians understand, interpret and express Islam as part of their lived experiences. Utilising the support of Muslim community organisations, groups and individuals to disseminate the survey, resulted in wide distribution and penetration into diverse communities and groupings of Muslims. The 1,034 Muslim Australian citizens and permanent residents who completed the survey were representative of the Muslim Australian population in relation to a number of key demographic indicators, including gender, 
age, country of birth, ethnic diversity and employment status.

While more than half of the survey respondents were raised in Australia (57 percent), others were raised in South Asia (23 percent), Western Asia, including the Middle East (12 percent), Southeast Asia (seven percent), Europe (five percent), Sub-Saharan Africa (five percent) and Northern Africa (four percent), among other regions of the world.

Another important factor in relation to the survey respondents concerns their religiosity and religious affiliation. An overwhelming majority (87 percent) said they "publicly/openly identify as a Muslim". A large majority of 77 percent said they prayed "daily", while seven percent pray "weekly", one percent pray "monthly", 12 percent pray "only on occasions", and three percent said they "never pray". Perhaps unsurprising given the topic of the survey, when asked how important Islam is to their identity, 80 percent said "very important", 16 percent said "important", while only three percent said "not very important" and one percent said "not at all important". This gave the researchers confidence that the survey responses reflect those of observant Muslims, sufficiently engaged with Islam to respond to the survey questions.

\section{Why asking Muslims is important}

Public debate about issues concerning Islam and Muslims has paid insufficient attention to Muslim voices and tends to be driven by pejorative commentary and opinion of others. Various studies and polls have recorded anti-Islam/anti-Muslim sentiments among 25-50 percent of the Australian population and a rise in reports of Islamophobia. Media coverage has tended to frame Islam and Muslims within the contexts of conflict, violence and terrorism. Social media has become a critical space where, as stated in a report published in The Guardian newspaper, "posts stoke deep hatred of Islam across the Western world and influence politics in Australia, Canada, UK and US" by blending "distorted news and total fabrication to paint Muslims as 
sharia-imposing terrorists...whose existence poses a threat to white culture and western civilisation".

While fears stoked by media coverage of Islam and Muslims in association with violent extremism are arguably misrepresentative, they are not unfounded. Australia's National Terrorism Threat Level assessment identifies the most likely perpetrators as "Islamist extremists". In 2014, as the threat of the so-called Islamic State of Iraq and Syria (ISIS) was growing, over 150 Muslim Australians were estimated to have joined the group and, at the time. Australia was thought to be the highest per capita exporter of foreign fighters. By 2019, around 50 Muslim Australians had been sentenced for terrorism offences. In response to this phenomenon, programs intended to counter violent extremism seemed to have the unintended result of officially reinforcing "many of the core stereotypes of Islam in the West: militancy, fanaticism, intolerance, fundamentalism, misogyny and alienness".

\section{Muslim Australians}

The extremist violence we have seen perpetuated over the past two decades under the banner of Islam is not normal. Muslims have lived peacefully in Australia for well over a century. The oldest mosque on the east coast of the country was built in Brisbane in 1908 by early Muslim Australians who settled in the late-1800s and made their living as farmers, hawkers and small business owners. My grandfather, Abdul Raheem Rane (d. 2006), was the first Imam of that mosque. Those who attended his sermons would recall his emphasis on being a "good citizen" and one's "duty" to society: "to be good and not hurt anybody, to be kind to everybody, to be charitable".

These words of compassionate, peaceful coexistence stand in stark contrast to what many Australians have come to think about Islam and Muslims, in part because they contradict what has been propagated by certain Muslim-majority governments, 
Islamist movements, and militant groups over the past several decades. Yet these words of Australia's first home-grown Imam represent the essence of Islam for the vast majority of Muslim Australians today.

\section{Survey findings}

The Islam in Australia survey found that the vast majority (89 percent) of respondents believe Islam aligns with human rights, civil liberties and democracy. A large majority (75 percent) characterise themselves as committed Muslims who believe in the rational, cosmopolitan nature of the Islamic tradition based on principles of social justice, gender justice and religious pluralism. Most of the survey respondents (59 percent) said they emphasise the spirit and ethical principles of Islam over literal interpretations; and almost as many (54 percent) said Islam is a matter of personal faith rather than a public identity. These convictions were apparent in response to a number of questions the survey asked concerning ethical, social and theological issues.

\section{Ethics}

The survey findings indicate that ethical considerations play a key role in how Muslim Australians think about Islam. In relation to human equality, 95 percent said "marriage should be based on mutual respect rather than the subservience of one spouse to the other", 93 percent said "people of all religion and no religion should be treated equally", and 84 percent said "women should be given the same rights and opportunities as men".

The issue of halal certification has also been a matter of controversy for many years, prompting claims that Islam promotes cruelty to animals. However, 92 percent of the survey respondents agreed or strongly agreed that "halal certifiers should assess the ethical treatment of animals as part of the halal certification process". 


\section{Issues of concern}

Among the issues about which respondents said they are concerned or very concerned, were media reporting on Islam and Muslims (96 percent), anti-Islam sentiment (94 percent), terrorism by right-wing extremists (93 percent), domestic violence (93 percent), mental health (93 percent), affordable housing (92 percent), treatment of asylum seekers (89 percent), climate change (89 percent), terrorism by Muslim extremists (88 percent), affordable higher education (87 percent), economic inequality (87 percent), Australian military intervention in Muslim-majority countries (86 percent), unemployment (85 percent) and reconciliation with Indigenous Australians (82 percent).

In spite of expressing such concerns shared by Australians in general, the survey found Muslims overall to be content with life in Australia. A strong majority (74 percent) were "content with the extent to which Muslims are currently able to practice Islam in Australia". Seventy-two percent said "Australia's legal system upholds the principles of justice and I am generally satisfied with it". Only 10 percent think that "countries today that implement classical shariah laws are more just and fair than Australia".

\section{Islamist influence}

Given that for the past several decades, countries such as Saudi Arabia and various Islamist groups have been active in propagating their particular interpretations of Islam globally, it is unsurprising that at least some Muslim Australians would be influenced by these and other interpretations associated with Islamist and jihadist ideology.

A large plurality (43 percent) identified as strict Muslims who follow Islam according to the laws of shariah, while a significant minority (21 percent) believes politics is part of Islam, and a small minority (eight percent) believes an Islamic political order and shariah should be implemented by force if necessary. The survey allowed for a 
closer look at individuals who identify with Islamist and jihadist ideology-essentially the pool from which those most vulnerable to the propaganda of groups like ISIS are drawn. Some of these findings confirm what we already know: they are more likely to be male than female, more likely to be their teens and 20s than their 30s and 40s, and less likely to have completed a university degree.

\section{Violent extremism}

Contrary to the well-worn stereotype associating Muslims with terrorism, 93 percent said "someone who dies attacking innocent civilians is not a martyr" and 90 percent said "Islam never permits armed conflict against civilians/non-combatants". Only four percent said "Islam sometimes permits armed conflict against civilians/noncombatants", while less than one percent said "Islam generally permits armed conflict against civilians/non-combatants", and six percent answered "don't know/unsure".

A cautionary note should be inserted here. Identification with ideas associated with Islamism or jihadism does not necessarily mean such individuals pose a security threat or that they are resistant to changing their views if credible information and education is provided.

Among the 34 respondents (3.3 percent) who "strongly agreed" with the statement "I am a committed Muslim who believes an Islamic political order and shariah should be implemented by force if necessary" and were hence classified as "militant", a large majority (74 percent) said "Islam never permits armed conflict against civilians/non-combatants" $(N=25)$, rather than it being "sometimes" $(N=6)$ or "generally" $(N=3)$ permitted. Only five of the 34 considered ISIS to be Islamic. Additionally, a large majority (71 percent) strongly agreed that "someone who dies attacking innocent civilians is not a martyr".

However, respondents categorised as "militant" were likely to have a politicised understanding of Islam with most (56 percent) believing that Islam advocates a 
particular political system and 74 percent agreeing or strongly agreeing that establishing a caliphate is a religious obligation. Thus, what is taught about Islam matters. Encouragingly, "militants" were more likely than not to believe that "engaging with non-Muslims as family, friends, colleagues and in general social interaction" is "good and normal" (53 percent) and were "completely open" or "very open" to "new knowledge about Islam" (85 percent).

While this indicates the influence of political Islamist and, to a much lesser extent, jihadist teachings and propaganda on a minority of Muslims in Australia, it also highlights the viable prospects for education about Islam, even among those who might be classified as extremists, radicals or militants.

\section{Importance of education}

When the survey respondents who possess an undergraduate university degree were compared with those who do not, a number of important differences were observed. As highlighted by other research, critical thinking skills are an important factor in the acceptance or rejection of ideas associated with religion, including those pertaining to conflict and relations with people of other faith groups.

The survey respondents who did not possess a university degree were more likely to say that Islam advocates a particular political system (overall, 25 percent; university degree, 22 percent; no university degree, 32 percent) and less likely to say it does not (overall, 49 percent; university degree, 53 percent; no university degree ,33 percent).[1] However, while respondents without a university degree were also less likely to strongly agree that an individual who attacks civilians is not a martyr (overall, 84 percent; university degree, 86 percent; no university degree, 63 percent), this was not a statistically significant difference.[2]

This suggests that while jihadist ideas do not find much acceptance regardless of one's level of educational attainment, higher levels of critical thinking skills may act as a protective factor against Islamist ideas. 
Encouragingly, even among those who have not attained a university degree, 86 percent considered engaging with non-Muslims as family and friends good and normal, and 85 percent are completely or very open to new knowledge about Islam. Among the survey respondents overall, 92 percent considered engaging with nonMuslims as family and friends good and normal and 88 percent were found to be completely or very open to new knowledge about Islam.

\section{Regional considerations}

Of all the world's religions, Islam may be the most important for Australia in the 21st century. This statement may raise eyebrows given that the number of Australians who profess no religion is rising and Australia's own Muslim population is officially just over 600,000 (2.6 percent of the total population) according to the 2016 census data.

However, the South/Southeast Asian region is home to the majority (62 percent) of the world's 1.8 billion Muslims and, according to the Pew Research Center, by the latter half of this century, Islam is expected to have more followers than any other religion on the planet, surpassing Christianity for the first time in history.

Our experiences with devastating wars and terrorism over the past two decades should be sufficient to deter us from allowing fear and misinformation to determine how Australians understand Islam and relate to Muslims going forward. Overcoming our prejudices concerning Islam and Muslims must involve acknowledgement of an ethical, progressive and peaceful Islam that teaches that respectful coexistence with non-Muslims is an authentic manifestation of Islam and is exemplified in the lived experiences of Muslims in $21^{\text {st }}$ century Australia.

[1] The odds of those without a university degree was $1.669(O R)$ times greater than the odds of those with a university degree believing Islam advocates a particular political system, 95\% CIs [1.046, 2.662], $p=0.032$. 
[2] The odds of those without a university degree $0.592(O R)$ was not significantly different to the odds of those with a university degree strongly agreeing that those who attack civilians are not martyrs, 95\% CIs [.346, 1.013], $p=0.055$.

Image credit: DisobeyArt/Shutterstock 